\title{
Celebrating the Reformation as transformation to dignity
}

\author{
Katts, Donald J \\ Stellenbosch University \\ djkatts@mweb.co.za
}

\begin{abstract}
South Africa is on an urgent journey of transformation toward a life of dignity for all. Dignity is at the heart of the South African Constitution of 1996. Some essential building-blocks of dignity are reconciling justice, responsible freedom, equality as equality of worth and equality as aequitas, equity and equilibrium. This paper will discuss how the theology of Reformers like Luther and Calvin informs our thinking about these central features of dignity. Calvin informs our thinking about justice and equality, and Luther informs our thinking about freedom.
\end{abstract}

Key words

Reformation; dignity; equality; justice; freedom

\section{Introduction}

The Latin word Reformatio literally means 'restoration or renewal.' When Luther started his onslaught on the Roman Catholic way of belief and religious practices, he and those who followed, actually set out to restore and renew not only the Church's religious thought and understanding, but Luther as the pioneer, as well as his followers, also wanted to renew their understanding of political power.

Thus, one can already detect here that religion and politics cannot be separated; they cannot be understood to be two railway lines that coexist next to each other, but have nothing to do with each other and never interact with each other. Reformation, therefore brought to light that politics needs religion so as to be just, fair, dignified and equal, fostering equality, equilibrium and aequity. Religion, on the other hand, helps 
politics to be free and so fosters freedom and helps ensure citizens who enjoy their freedom responsibly.

Likewise religion needs politics for the simple fact that as politics evolves, develops and grows, it challenges religious precepts, concepts, dogma and beliefs. Politics is necessary for religion to adapt, renew and, perhaps, be transformed so as to stay relevant and to continue being a key role player in building not only citizens who treasure and acknowledged their own dignity, and respected the dignity of others, but helping to establish a humane society, where all is free, equal and treated justly.

\section{The theology of Reformers thicken our understanding of notions like dignity, justice, equality and freedom}

South Africa is a multi-cultural, multi-religious, ethnically diverse and economically unequal society. Prior to 1994, theology was one of the major role players in bringing Apartheid to its end. Today it still plays a vital role in building a humane society in which the dignity of all is acknowledged and respected, so fostering human rights, equality and responsible freedom. It was especially the theological understanding and insight of the Reformers that gave impetus to putting Apartheid in its reformed perspective and thus emphasising concepts like dignity, justice, equality and freedom.

\subsection{Dignity - Theology says it is Trinitarian ${ }^{1}$}

The theology of the Reformers enhances our understanding of dignity in that it argues that every person has an inalienable dignity. It teaches that all humans were and are created in the image of God $\left(\right.$ Calvin $\left.^{2}\right)$.

We can therefore say that our dignity has Trinitarian sources. Our dignity is based in the person and work of the creating Father, the electing Father,

1 For the notion of Trinitarian dignity, the insights of John Webster and Nico Koopman are richly drawn upon. (Webster, J. The Dignity of Creatures, in P Middleton (ed.), The Love of God and Humanity Dignity. Essays in Honour of George M. Newlands (London: T\&T Clark, 2007), pp. 19-33. Koopman, N. Human dignity in the context of globalization, in Boesak, A and Hansen, L (eds), Global crises, global challenge, global faith. An ongoing response to the Accra Confession. (Stellenbosch: Sun Press), pp. 231242.

2 See John Calvin, Institutes of the Christian Religion, trans. Henry Beveridge (Massachusetts: Hendrickson Publishers, 2008). 
the providing Father, the caring Father. Our dignity resides in the fact that God takes human beings so seriously that God became human in Jesus Christ, the kenotic Christ, the incarnated Christ, the crucified Christ, the resurrected Christ, the ascended Christ, the reigning Christ, the returning Christ. Our dignity is based in the person and work of the Holy Spirit, the indwelling Spirit, the working Spirit, the actualizing, operationalizing, implementing, materializing, embodying, shape-giving, fulfilling Spirit, the transforming Spirit, the renewing Spirit, the perfecting Spirit.

\subsubsection{Our dignity resides in the loving act of God}

Our dignity resides in the loving act of God, the creator who summons us into being. Our dignity is a created dignity. Our vulnerability, as expressed in our creaturely needs, is not in conflict with our created dignity. Our needs reflect our dependence upon God who summoned us into being and who gave life to us, and who fulfils and consummates a life of full glory for us.

Human dignity as responsible selfhood, identity across time and creaturely continuity cannot be had remoto Deo, i.e. in separation from the creator's summons. Dignity does not reside in autonomy and independence, but in this dependence upon God the creator. The dignity, worth, honour and glory of creatures rest in our calling by God to live in fellowship and communion with Him. Webster states:

God crowns creatures with glory and honour, marking them out as the recipients of his approval, and setting them apart for fellowship with himself. Creation is exaltation; creatures have dignity as they are dignified by God (Webster 2007:24).

From this divine foundation of our dignity emanates the theological imperative to acknowledge and respect dignity. According to Webster:

Only God the creator can crown with glory and honour; creatures are not competent to ascribe dignity to themselves or to other creatures. Human judgements about dignity can only be repetitions of the divine judgement, acts in which honour is recognised as an indicative and imperative which rests on the divine decision (Webster 2007:24). 
Human dignity as created dignity means that we receive our dignity from the creator. Our dignity is inalienable because it is given by the creator. It is inalienable because it does not come from humans, but it comes from the creator. It is inalienable because it is not dependent upon the recognition of dignity by the frail and unreliable hearts, minds and actions of humans, but it is dependent upon the living God. Creaturely dignity as inalienable dignity implies that our dignity does not reside in our own merit, capabilities and performance. Inalienable, creaturely dignity is received dignity. It is dignity in the presence of, in communion with, and in dependence upon God the creator.

Our calling with regard to acknowledging and affirming, actualising and fulfilling dignity is to witness in word and deed to the dignifying decisions and actions of God the creator. But even our unfaithfulness to this calling does not mean that people can be alienated from their dignity. We may deny, disregard, disrespect, betray, abuse and violate this dignity, but we cannot rob or alienate people from their God-given, creaturely dignity.

Webster refers to the fact that the creator calls us to enact our being in fellowship with Him. The Christian tradition teaches that this human being is created in the image of God. And as his image we share in God's freedom, authority, creativity, rationality, responsibility and in his desire and capability to live life in communion.

Through the lens of Webster these features are defined and substantialised in terms of the recognition of the vulnerability of humans who are called to live in dependence upon and in communion with God. Therefore our freedom is in harmony with God's freedom, which is always a freedom for the other, specifically for the suffering other. Our authority is always authority received from the creator and therefore redemptive, serving and liberative authority. Our creativity, work and labours are to create for the sake of communion and joy. Our rationality reflects the rationality and logic of God, and therefore transcends the modernistic criteria of rationality, namely that which makes logical sense and that which can be empirically verified. Our desire for communion resonates with God's desire for and realisation of a communion of care and solidarity, mutuality and reciprocity. 


\subsubsection{Our dignity is also christologically based}

Our dignity is also christologically based. Webster argues that a theology of dignity should be developed within the context of Saint Augustine's appeal that dignity discourse should be part of hamartiological and soteriological discourse. As human beings we cannot destroy our dignity, but we can alienate ourselves from the relationship with God our creator. Human dignity can only flourish in the context of a relationship with God where we thankfully accept the gift of dignity and our calling to live a dignifying life. We trample on our dignity through two sinful ways; through our rush for carnal fulfilment and dishonourable passion, as well as through our conviction that we ourselves, and not God, are responsible for the establishment and protection of our dignity. This carnality and skewed form of responsibility are ways of refusing to accept the gift of dignity. This refusal to accept the divine gift, according to Webster, causes alienation and misery:

The sinful state which eventuates may be characterised by alienation (the objective breach of relations between creator and creatures in which creatures come to discover that they have placed themselves at a mortal distance from the source of life and blessing) and by misery (the subjective degradation which comes from the futile attempt to have life on conditions other than those established by the creator's love) (Webster 2007:26).

Where we isolate ourselves from God, and where we follow our own logic for our lives instead of God's logic, there we do not enjoy the blessing of dignified living that God has in store for us.

Through the Person and the extensive and comprehensive work of Jesus Christ God affirms our dignity. According to Webster Christ affirms and protects our dignity "by the full scope of this divine mission: its origin in the eternal procession of the Son; the assumption of flesh; the state of humiliation; the exaltation of Easter; the glorious rule of the Son as the ascended and enthroned reconciler who presents himself in the Spirit's power (Webster 2007:29)."

Through the work of Christ God provides a way for sinners to live in communion with Him again, to accept his gift of dignity and the vocation 
to live and witness to a God-given life of dignity. In this regard Webster cites Calvin's comment on Psalm 8:

... the heavenly Father has again bestowed the fullness of all gifts upon his Son, that all of us should draw out of this well-spring: whatsoever God bestows upon us by him, the same of right belongs in the first degree to him; yea, rather, he is the lively image of God, according to which we must be amended, upon which all other things depend.' And so: 'His excellence and heavenly dignity are extended unto us also, for whose sakes he is enriched with them (Webster 2007:29; in Calvin, A Commentary on the Psalms, Vol 1 [London: Clarke, 1965], pp. 93-94).

The gift of creaturely dignity that humans due to sin do not fully accept and enjoy, is embodied by Jesus Christ. Christ is the perfect human which fully accepts and enjoys the gift of creaturely dignity. Thereby He confirms this dignity and enables us as sinful humans to accept and enjoy the gift. Only through Christological dignity do we accept and enjoy creaturely dignity. The dignity and glory of Christ is pro nobis. It is for us, it is our dignity.

\subsubsection{Our dignity is also based in the person and work of the Holy Spirit}

Our dignity is also based in the person and work of the Holy Spirit. The Spirit is the Spirit of God through whom God perfects and actualises the dignity of human beings in correspondence to God's plans and purposes, calling and summons. The Spirit is the Spirit of Christ through whom the glorified Son directs creaturely realities to their completion. In this journey the Spirit generates, sustains and purifies obedience and active consent on the part of creatures.

Webster states:

The Spirit moves creatures, and in moving gives them their proper spontaneity and integrity, that is, their dignity as the active children of God (Webster 2007:30).

Dignity is actualised in the Christian communion, in the Trinitarian communion, in the church. In communion with the triune God our dignity is created, confirmed and actualised. In communion with fellow creatures it becomes clear that this dignity is not only metaphysical, but that it is also orientational and moral. Dignity as a gift from God also takes on 
social shape and form amongst God's creatures. Our moral imperative is to acknowledge, protect and testify to this Trinitarian and ecclesial dignity. We are called upon to resist the denial and betrayal of dignity.

This Trinitarian dignity is bestowed upon all human beings, both male and female, and for that matter, also upon people with all other sexual orientations.

In pluralistic public discourses theology put these thicker or more comprehensive understandings of the roots of our inalienable dignity on the table. Theology does this in humble, hospitable and, as far as possible, in an intellectually accessible manner.

\section{Justice}

Just as dignity is portrayed as the dignity forthcoming from God, so we can argue that justice is forthcoming from God. Justice is the justice of God. Four decades ago B Wentsel ${ }^{3}$ discussed justice as God's justice. He argues that God's justice is constituted by a threefold virtue, namely justice as norming and guiding justice for all walks of life, justice as retributive justice, and justice as salvific justice.

All these dimensions of justice are based in the notion of the work of justification of the triune God. Justification entails that the triune God justifies and sanctifies sinners. God brings forgiveness and salvation, justification and sanctification. He transforms people into justified and sanctified ones who receive the vocation to seek justice in the world. Justification and sanctification are interdependent. We cannot talk about one without the other. Moltmann, ${ }^{4}$ in line with Luther and Calvin, describes justification as mortificatio sui, the dying to the self, and sanctification as the vivificatio Spiritu, life in the Spirit.

3 B. Wentsel, Hij voor ons, wij voor Hem. Over gerechtigheid, verzoening en gericht (Kampen: Kok, 1973), pp. 50-57.

4 J. Moltmann, The Spirit of life: A universal affirmation (London: SCM, 1992), pp.163165. 
Justification paves the way for seeking justice in the world. Paul Lehman, ${ }^{5}$ who argued against the unhappy divorce between soteriology and ethics, views justification as what God does to set things right between humans and God. Justice, as the human quest to set things right amongst humans, is our faithful response to these actions of God. "When justice is understood as the setting right of what is not right in man's (sic.) relationship to man (sic), both private and public, then, the struggle for justice becomes the concrete expression, in behaviour, of man's (sic.) response to what God has done and is doing to set things right between man (sic.) and Himself" (Lehman: 1967). The faith by which man is justified becomes what Luther called a 'busy, living, active thing' by who men learn in the struggle for justice what it means concretely to forgive and to be forgiven. Luther's notion of living and effective faith parallels his understanding of justification as dynamic and effective, as the divine bringing forth and making of humans who are simultaneously sinful, on the one hand, and forgiven and just, on the other hand. These justified ones are continuously in search of personal and social justice through a process of self-judgement and repentance.

In a very helpful article Mark Seifrid discusses Melanchton's and Luther's views on justification ${ }^{6}$. He is concerned that Melanchton interprets the important notion of the imputation of Christ's righteousness in a reductionist way. He reasons that Melanchton views justification - in an arid, juridical manner - as a means of quieting the conscience, and as a means of inward renewal. He runs the risk of viewing justification as a human possession, a human virtue. He does not view justification as a dynamic, sanative and continuous action of God, as Luther does. For Luther, according to Seifrid, ${ }^{7}$ the imputation of righteousness is not merely the initial act by which God imparts salvation, but rather the continuous way in which God governs and purifies the life of the justified. It is a forensic and declaratory act, but it is also more. It is also an effective word of God,

5 P. L. Lehmann, "Forgiveness", in J Macquarrie (ed.), The Dictionary of Christian Ethics (Philadelphia: Westminster Press, 1967), p. 131.

6 M. A. Seifrid, "Luther, Melanchton and Paul on the question of imputation", in M Husbands and DJ Treier (eds.), Justification. What's at stake in the current debates? (Downer's Grove, Illinois: InterVarsity Press/ Leicester, England: Apollos, 2004), pp.148-150.

7 M. A. Seifrid, Luther, Melanchton and Paul, p. 145. 
which paves the way for faith, daily repentance and self-judgment by which God 'makes out of unhappy and proud gods, true human beings, that is, wretches and sinners ${ }^{8}$.' We might conclude that for Luther the divine declaration of justification is, therefore, also a continuous divine making into a just person of the sinner?

Based on the idea that through justification God transforms human beings into righteous and just persons, Stanley Hauerwas argues that the task of Christians is not only to formulate theories of justice, but in the first place and fundamentally to be just persons.

... for Christians, justice is first and foremost a claim about the kind of people we ought to be. You cannot have, contrary to liberal assumptions, a just social system, without people being just. The attempts to create such systems end in creating greater state power in the name of doing justice. Christians do not need such accounts of justice to know that the ill need care and the hungry need food. By learning to share their lives in the church, Christians have learned that justice often demands no more than the most common acts of care. ${ }^{10}$

The author of this article understand Hauerwas's plea to be one that expresses the confidence that just people, people who do not forget the most basic calling to care, are well placed to participate in the public quests for theories and systems, policies and practices of justice.

8 Luther, as quoted by MA Seifrid, Luther, Melanchton and Paul, p. 151.

9 Seifrid's summary of Luther's dynamic understanding of justification, and of its implications for a life of personal and social justice, amidst sin and injustices, might be quoted at length:

Luther's dynamic conception of justification much more effectively conveys the way in which God's mercy is granted only in judgment. The justification of the sinner takes place only in and through the justification of God in the event of the cross and resurrection of Jesus Christ. "Justification" is no mere transaction to be applied to my account. God's "yes" is given only in and with his "no," a "no" and "yes" which are mine only in so far as faith echoes them in my heart. Both in the foolishness of pride and sin and in the despair of misery, suffering and failure, this Gospel of the justifying work of God in Christ both conquers and carries us sinners.

10 S. Hauerwas, "Should Christians talk so much about justice?", in B\&R Reviews May/ June 1986, p. 6. 
This discussion hopefully sheds some light on the relationship between God's justice and human justice, between justification and justice.

Where human justice is based in God's justice, a richer understanding of justice is developed. We might identify two dimen sions of the compassionate justice of article three of the Belhar Confession. It can be argued that the notion of compassionate justice implies that justice has a forensic or legal dimension and that it also has features like mercy, sacrifice, righteousness, reconciliation and restoration.

The Old Testament uses justice mainly in a twofold way, i.e. as forensic justice (mishpat), and as compassionate justice (tsedaqah). The New Testament dikaiosune, carries both meanings. Bruce Birch ${ }^{11}$ describes mishpat as a term with a basic forensic character. It deals with judicial activities at every level. It is an ethical concept that deals with rights due to every individual in the community and with the upholding of those rights. Especially God's justice refers to the upholding of the rights of the vulnerable, and with the advocacy of their needs (Deut.10:18; Ps.10:18; Jer.5:28). Where the rights of the vulnerable are violated, God's justice can be translated as judgement, the activity of God to hold accountable those who deny, manipulate and exploit the rights of others. Various theories of justice that developed in the post Enlightenment era also strive to employ justice, amongst others through the notion of human rights, as a pathway towards homecoming for millions, i.e. enjoying the good of the land.

Tsedaqah, according to Birch ${ }^{12}$, is also translated as righteousness. Here the focus is on right relationships. God's righteousness refers to his concrete acts to establish and preserve relationship. His law is a gift that aims at establishing terms under which relationship is preserved and maintained ${ }^{13}$. Both the Old and New Testaments teach that sacrifice was required to achieve this rightness in relations. Justice therefore stands in relationship to justification. Justification means that we are declared righteous by God because of the ultimate sacrifice of Christ. This imputed righteousness,

11 B. C. Birch, Let justice roll down. The Old Testament, ethics, and Christian life (Kentucky: John Knox Press, 1991), pp. 155-156.

12 Ibid., pp. 153-154.

13 Tsedaqah can also be translated as vindication, deliverance, uprightness, right and even prosperity. 
i.e. righteousness that we possess because of our connectedness in faith to Christ, makes us people who practice justice. Those who are made righteous through a sacrifice also practice sacrificial justice. They know that relationships will not be right and prosperous and joyful without sacrifice.

A crucial dimension of justice is equality. Duncan Forrester ${ }^{14}$ argues that equality refers to equality in worth, dignity and value. Inequality is witnessed to in evils like racism, sexism, anti-Semitism, etc. Forrester, however, concedes that there is disagreement on how this equality of worth can be translated into policy and practice.

\section{Equality}

Oliver O’Donovan argues against an absolutistic equalization process. O'Donovan is in favour of the notion of the equal worth of humans. He, however, reckons that this theological and metaphysical notion, which constitutes the foundations of society, should not be confused with the superstructure of human existence. Where revolutionary equalization causes this confusion, social structures are dissolved and degraded, and human life becomes unliveable. The metaphysical foundational principle of equal worth cannot be implemented in society without taking the complex differentiated nature of the structures of society into consideration. For him differentiation is the law of every social organism. Attributive justice, as justice of differentiation, is influenced by notions like affinity and bonds of loyalty, the promotion of talent, wise appointments to office, the provision of opportunities to those who could use them. "We depend on the justice of differentiation from the moment we take our first breath and are placed in the arms of our mother, rather than being handed to whoever may be next in the queue for a child." ${ }^{15}$ O'Donovan does, however, caution that this emphasis on justice of differentiation should not close our eyes for those kinds of difference which are simply unjust.

14 D. Forrester, On human worth (London: SCM Press, 2001), p. 30.

15 Ibid., pp. 42. 
O'Donovan ${ }^{16}$ suggests that we view persons as always equal in worth, but that we differentiate in roles and classes. Roles that we play are distinguished from each other and are not equal in an absolutistic sense. In the same way classes, communities and collectives e.g. genders do have differences. Allocations to men's' health care and women's' heath care, to boys' education and to girls' education should not be done on a 50-50 basis, but in terms of what each requires in specific contexts and instances. He employs Paul's words in Galatians 3:28 to argue against the absolute or revolutionary equalization of classes.

Despite his plea for equality in the context of the justice of allocation and differentiation he identifies three thresholds where the metaphysical equality of worth should also be adhered to in practices and policies. There should be strict equality in cases where we fight against death for the saving of life. ${ }^{17}$ There should be strict equality with regard to the opportunity to live and to participate in society, since these constitute part of the heart of worth and dignity. ${ }^{18}$ The third threshold for strict equality is the equality before the law, where prosopolempsia, i.e. prejudice against the person, should not determine the process. ${ }^{19}$

In a very illuminating article, Bram van de Beek $^{20}$ showed a few years ago how Calvin's perspectives on equality can enrich contemporary discussions on justice and equality in our pluralistic public domains. Van de Beek argues that equality cannot be understood as absolute equality. Equality should rather be understood in terms of the notion of aequitas that Calvin employs. Aequitas refers to the quest for equilibrium, for balance ('ewewig') in society. It implies that we need equity (from aequitas) measures to build a society of greater equilibrium; a society of balance, of moderation, where some do not have too much and others too little. A society of equilibrium is enhanced where we practice an ethos of self-denial, sacrifice, service and

16 Ibid., pp. 43-44, 50-51.

17 Ibid., p. 44.

18 Ibid., pp. 48-49.

19 Ibid., pp. 49-50.

20 A van de Beek, "Beyond the unfounded optimism of equity", in E van der Borght (ed.), Affirming and living with differences (Zoetermeer: Meinema, 2003), pp. 147-160. 
care, and where we do not only bear the burden of the other, but where we bear the other one as burden.

Justice and equality is due to all people and creatures, because we have God-given, and therefore, inalienable, dignity, worth and value. South African theologians like Desmond Tutu, Allan Boesak, John De Gruchy, Charles Villa-Vicencio, Denise Ackerman, Dirk Smit, Nico Koopman and many others share these understandings of dignity, justice and equality and used them to propagate the fall of Apartheid and, as we journey to a society of dignity, they still argue for reconciliation, justice, quality and freedom.

Furthermore, we can say that justice is only present where freedom prevails.

\section{Freedom}

'Christianus homo omnium dominus est liberrimus, nulli subiectus. Christianus homo omnium servus est officiosissimus, omnibus subiectus. ${ }^{.21}$ - 'A Christian is a perfectly free lord of all, subject to none. A Christian is a perfectly dutiful servant of all, subject to all.'

According to reverend Travis J. Loeslie (pastor of St. Peter Lutheran Church in Lester Prairie, MN), Luthers paradoxical teaching of Christian freedom, following Christ and St. Paul, joins lord and servant in one person. By faith alone, God sets a man utterly, completely, free in Christ. He is lord of all, subject to none. Love binds him as an utterly dutiful servant to the neighbour, subject to everyone. The paradox of Christian freedom then plays out in faith and love.

The 'freedom' Luther has in mind is deeply relational. As he makes clear in 'The Freedom of a Christian,' it is found in a relationship with Christ, who has liberated the self from a horizon limited by the forces of 'sin, death, and the devil'.

Furthermore, as Luther makes clear, for the one on whom this freedom is conferred, the world now becomes an arena for service and good works. The bondage formerly known in relation to 'sin, death, and the devil'

21 See more at: http://lutheranreformation.org/theology/on-the-freedom-of-a-christian/\#_ftn1 
is transferred now to the needs of the neighbour and the world, but the motivation is completely transformed. The very love that has enabled freedom now flows forth in service. ${ }^{22}$ It is not timid or sentimental; the shape of this love itself is cruciform. Consequently, those held by this love should not be surprised to find themselves in the midst of a remarkable adventure that reflects both the suffering and joy of Christ's death and resurrection. As Luther says in 'The Freedom of a Christian': "From faith there flows a love and joy in the Lord. From love there proceeds a joyful, willing, and free mind that serves the neighbour and takes no account of gratitude or ingratitude, praise or blame, gain or loss. We do not serve others with an eye toward making them obligated to us. Nor do we distinguish between friends and enemies or anticipate their thankfulness or ingratitude. Rather we freely and willingly spend ourselves and all that we have" (Lutheran Reformation: [Online]).

Serene Jones ${ }^{23}$ identifies five forms of oppression that we need to be freed from, namely freedom from exploitation, freedom from marginalisation, freedom from powerlessness, freedom from cultural imperialism, and freedom from violence.

\section{Reception of Calvin's and Luther's theological and ethical thought by South African theologians}

From Luther's teaching on Christian freedom, as stated in his famous quotation at the beginning of this section, one can detect that Luther also calls one to freedom, to just practises, equal treatment and respect for others. His understanding of freedom is one that invites one to freedom of service, free to share and care. As the South African theologian, Denise Ackerman noted; 'Was theirs (Reformers) not a journey of 'freedom from' to 'freedom for ${ }^{24}$ '.

22 A classic study in Luther's ethics is George Forell's Faith Active in Love (New York: American, 1954).

23 S. Jones, Feminist theory and Christian theology. Cartographies of grace (Minneapolis: Augsburg Fortress Press, 2000), pp. 79-93.

24 D. Ackerman, Surprised by the man on the borrowed donkey. Ordinary blessings (Cape Town: Lux Verbi, 2014), pp. 155. 


\subsection{On freedom}

It is this kind understanding of freedom that inspired South African theologians to call on all its citizens to become involved in public strategies to fight the oppressive, racist and dividing Apartheid policies, and to work for a democratic, free, inclusive, non-racial, just and equal society where dignity reigns.

Ackerman helped us by, firstly, picturing this 'freedom for' as abundance; meaning that we discover a sense of fullness, wholeness, and the desire to share our bounty (Ackerman 2014:165). Secondly, she thinks of hope. Being 'free for' is to live with hope, because we know hope ourselves. As she quotes Heb.11:1, she goes on to argue that "Freedom in faith rests solidly on the belief that God has given us our freedom, that we have to accept and enjoy it, and that we dare to hope and trust that we can move beyond all that limits our freedom into a space that is filled with a lightness of being which we call 'freedom'. Then we can become communities of hope" (Ackerman 2014:166). Thirdly she thinks “'freedom for' is to be free to love my neighbour as myself ... which is expressed by sharing with and caring for one another" (Ackerman, 2014:166). It is this understanding of freedom that helped South Africa on its journey to dignity.

\subsection{On equality, dignity and justice}

On the question of equal dignity and justice, Tutu ${ }^{25}$ reminds us that "there is another kind of justice: restorative justice, whose chief purpose is not punitive but restorative, healing. It holds as central the essential humanity of the perpetrator of even the most gruesome atrocity, never giving up on anyone, believing in the essential goodness of all as created in the image of God, and believing that even the worst of us still remains a child of God with the potential to become better, someone to be salvaged, to be rehabilitated, not to be ostracised but ultimately to be reintegrated into community" (Tutu. 2011:42). He further said that "I could not have fought against the discrimination of apartheid and not also fight against the discrimination that homosexuals endure, even in our churches and faith groups ... Opposing apartheid was a matter of justice. Opposing discrimination against women is a matter of justice. Opposing discrimination on the basis

25 Tutu, D. 2011. God is not a Christian. Speaking truth in times of crisis. (London, Rider). 
of sexual orientation is a matter of justice." "We are all equal, of equal worth in the sight of our Father. All, all belong: gay, lesbian, so-called straight." (Tutu. 2011:54-56). De Gruchy holds the view that "restorative justice' is not, however, a weak form of justice, a dilution of the normal legal process. Nor does it necessarily exclude other forms of justice, even retribution or the use of punishment as a deterrent." Restorative justice is rather the attempt to "recover certain neglected dimensions that make for a more complete understanding of justice." Its emphasis is on rehabilitation, on compensation, on the recovery of dignity and the healing of social wounds. This he continues, "is precisely what is at the heart of justice in the biblical tradition; it is relational and social, it requires both embrace and the overcoming of oppression in all its forms." (De Gruchy 2002:203).

Pillay also argues for the equality of men and women when she adds her voice "to those who believe that it is not important to find the maleness or femaleness of God so that we (Christians, who are either female or male, can align ourselves with God and thereby affirm our superior nature, but that we find our common humanity, our equal human dignity, in God incarnate through the birth, life, teaching, death and resurrection of Jesus of Nazareth. ${ }^{26}$

\section{Conclusion}

This paper argued that the theological insights of Calvin (justice and equality) and Luther (freedom) enrich our contemporary public theological discussions and our broader interdisciplinary public discourses about themes like dignity, justice, freedom and equality. From their theological and ethical insight South African theologians in particular have developed their reformed theology and offered a richer way of describing the notions like dignity, justice, equality and freedom, which all enhance and help to guide our journey to a society of dignity, equality and responsible freedom. Thus we celebrate Reformation as transformation to dignity. Reformed theology also assisted us in identifying and mobilising the resources in

26 M. Pillay, "Rereading New Testament text: A public-theological resource for addressing gender inequality in the context of HIV/Aids in South Africa", in L. Hansen (ed) 2007, Christian in Public: Aims, Methodologies and issues in public theology (Stellenbosch: African Sun Media, 2007), 212-213. 
faith communities, civil society and also in political and economic life to actively transform our once Apartheid South Africa to a democratic, inclusive, equal, free and just South Africa. We are not fully there yet, but as we journey together, we shall continue to work together on lighting the path on how to get there.

\section{Bibliography}

Ackerman, D 2014. Surprised by the Man on the borrowed donkey. Ordinary blessings. Cape Town: Lux Verbi.

Birch, BC 1991. Let justice roll down. The Old Testament, ethics, and Christian life. Kentucky: John Knox Press.

Calvin, John 2008. Institutes of the Christian Religion (translated Beveridge, H). Massachusetts: Hendrickson Publishers.

De Gruchy, J 2002. Reconciliation - Restoring justice. Minneapolis:Fortress Press.

Forrester, D 2001. On human worth. London: SCM Press).

Hauerwas, S 1986. “Should Christians talk so much about justice?” B\&R Reviews, May/June.

Lehmann, PL 1967. “Forgiveness”, in J Macquarrie (ed.), The Dictionary of Christian Ethics. Philadelphia: Westminster Press.

Lutheran Reformation. [Online] Available: http://lutheranreformation.org/ theology/on-the-freedom-of-a-christian/\#_ftn1 [Accessed: 8 August 2016].

Moltmann, J 1992. The Spirit of life: A universal affirmation. London: SCM.

Pillay, M 2007. Rereading New Testament text: A public-theological resource for addressing gender inequality in the context of HIV/Aids in South Africa, in L Hansen (ed) 2007, Christian in Public: Aims, Methodologies and issues in public theology. Stellenbosch: African Sun Media. 2009-225. 
Seifrid, MA 2004. "Luther, Melanchton and Paul on the question of imputation", in M Husbands and DJ Treier (eds.), Justification. What's at stake in the current debates? Downer's Grove, Illinois: InterVarsity Press/Leicester, England: Apollos.

Tutu, D 2011. God is not a Christian. Speaking truth in times of crisis. London: Rider

Van de Beek, A 2003. Beyond the unfounded optimism of equity, in E van der Borght (ed.), Affirming and living with differences. Zoetermeer: Meinema. p.147-160.

Wentsel, B 1973. Hij voor ons, wij voor Hem. Over gerechtigheid, verzoening en gericht. Kampen: Kok. 